\title{
Risk factors and plant management activities for the terraced agricultural systems on the Amalfi coast (Italy): an interdisciplinary approach
}

\author{
Emanuela Cicinelli ${ }^{1} \cdot$ Giulia Caneva $^{1} \cdot$ Valentina Savo $^{1}$ (I)
}

Received: 27 April 2021 / Accepted: 10 August 2021 / Published online: 9 September 2021

(C) The Author(s) 2021

\begin{abstract}
Cultivated terraces are outstanding modifications of mountains and hills to obtain arable land. These terraced agricultural systems are widespread traditional landscapes within the Mediterranean area. The cultivated terraces of the Amalfi Coast (Southern Italy) are outstanding examples of cultural landscapes, and they represent one of the key descriptors of the UNESCO Site. Terraces have characterized the landscape of the Amalfi Coast for a long time as their construction started during the Middle Age. However, their conservation is now threatened by abandonment, which has dramatically risen in the last 60 years, and by the ongoing climatic changes with the increased incidence of heavy rainfall events. We combined interviews with local farmers and vegetation surveys to understand which management activities are carried out to improve the conservation of cultivated terraces on the Amalfi Coast. To this end, we analyzed the linkages between these management practices and their influence on the vegetation growing on the terrace risers. Our informants identified the maintenance of waterways and walls as crucial factors influencing terrace and slope stability. The preservation of the integrity of terraces depends on periodic vegetation control and the maintenance of water drainage systems, which are carried out thanks to the active presence of farmers. According to our informants, the vegetation growing on the walls has a relevant role in the stability of terraces, and we found a prevalence of Hemicryptophytes that increase with the number of interventions over the year. Thus, active and vital agriculture becomes pivotal for the preservation of this cultural heritage.
\end{abstract}

Keywords Cultivated terraces - Management of agricultural systems · Mediterranean vegetation - UNESCO World Heritage Site $\cdot$ Landscape conservation · Local Ecological Knowledge

\section{Introduction}

Cultivated terraces are quite ancient and widespread across continents (Spencer and Hale 1961; Doolittle 1990; Treacy and Denevan 1997; Wei et al. 2016). In many parts of the world, agriculturists have shaped mountainsides to obtain arable land where it was limited (Andlar et al. 2017), showing the human ability to adapt to different conditions and environments (Agnoletti et al. 2015). Many terraced systems are today considered cultural landscapes and are often managed with traditional techniques, which generally preserve natural biodiversity and ecological functionality (Baiamonte

Valentina Savo

valentina.savo@uniroma3.it

1 Department of Science, University Roma Tre, Viale Marconi 446, 00146 Rome, Italy et al. 2015). However, these features of terraced landscapes, along with their aesthetic values, are retained only in wellpreserved terraces. To date, a total of 25 terraced landscapes are listed among UNESCO's Cultural Heritage Sites, with a concentration in the Mediterranean area (Kladnik et al. 2017).

Although there are different types of terraces, in the Mediterranean area bench terraces are the most common, with risers mostly made of stones (Stanchi et al. 2012; Wei et al. 2016; Cicinelli et al. 2021). These terraces typify marginal lands in Spain, Greece, Israel, Italy, Croatia and other Mediterranean countries (García-Ruiz et al. 2013; Arnáez et al. 2015; Wei et al. 2016; Andlar et al. 2017) and they have been built with construction techniques that have not changed much over time (Bevan and Conolly 2011; Morenode-las-Heras et al. 2019). The construction and maintenance of drystone terraces are quite labour-intensive and entail specific knowledge, which is now disappearing as 
agriculturists abandon their lands, terraces, and traditional practices (Hribar et al. 2017; Pipan et al. 2017; Zoumides et al. 2017). The traditional management of terraces can preserve biodiversity, enhancing landscape heretogenity and creating microhabitats (Van der Sluis et al. 2014; Solomou et al. 2020). The lack of maintenance has often been related to terrace collapses and the loss of the linked cultural landscapes all over the Mediterranean area (Cicinelli et al. 2021).

Like other South-Thyrrenian coasts of Italy, the landscape of the Amalfi Coast is typified by rugged coasts, woodlands, and here agricultural land was stolen from the steep mountains thanks to stonewall terraces. Therefore, terraced vineyards and orchards are identified as key descriptors of the Amalfi Coast, which was recognized as a Cultural Heritage Site in 1997 (UNESCO 1997). The protection and conservation of terraced landscapes in Italy pertain to the Superintendency for Architectural Heritage and Landscape (Ministry of Culture), such as the National Register of Historical Rural Landscapes and Traditional Practices (Ministry of Agriculture Food and Forestry Policies), and farmers are eligible for funding for their preservation (Caneva et al. 2013; Agnoletti et al. 2015; Varotto et al. 2019). Although there are economic incentives, the unique landscape of the Amalfi Coast is currently threatened by the potential collapse of terraces once they start deteriorating after the abandonment of agricultural activities; the risk of these collapses is also amplified by the increasing incidence of heavy rainfall events (Caneva et al. 2007; Caneva and Cancellieri 2007; Caneva 2010; Savo et al. 2016). In this area, the new touristic-oriented economy has polarized the local businesses and lured younger generations that are no longer interested in cultivating the land (Savo et al. 2014).

Starting from our knowledge of climate, vegetation, and ethnobotanical traditions of the area (including our surveys carried out for the management plan of the UNESCO site), here we explore traditional ways used to preserve the terraced landscape of the Amalfi Coast (Fig. 1). In this study, we adopted an integrated interdisciplinary approach, linking ecological considerations (vegetation surveys on inuse terraces) with the Local Ecological Knowledge (LEK) (Berkes et al. 2000) of traditional farmers. The traditional management of terraces has preserved terraced landscapes for centuries and it is widely reported that abandoned terraces are more likely to collapse (Cicinelli et al. 2021 and references therein), We assumed that there are key traditional management activities that can reduce the risks of terrace collapses. In this study, we combine semi-structured interviews with traditional farmers and vegetation surveys on in-use terraces to understand which are the most relevant perceived factors of risk and the management activities that are performed. We also assumed that the vegetation growing on the terrace risers can affect their

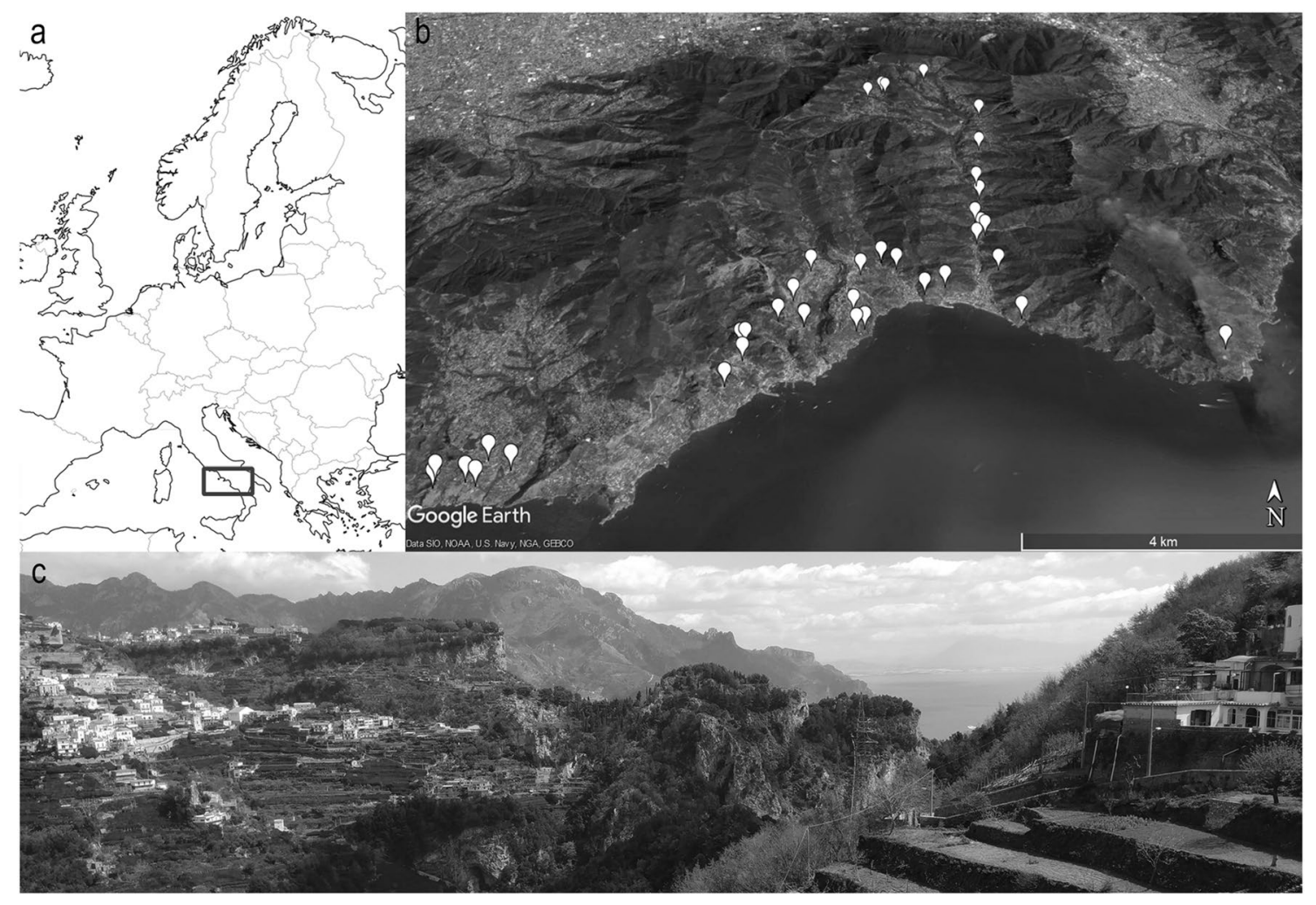

Fig. 1 a The geographical position of the study area; $\mathbf{b}$ The location of the sampling sites; $\mathbf{c}$ A typical terraced landscape on the Amalfi Coast 
stability as shown in studies on the preservation of walls of archaeological sites (e.g., Caneva et al. 2018). Thus, we also try to assess how management activities affect the floristic composition of the walls and influence the maintenance of terraces and consequently the preservation of the cultural landscape.

\subsection{The terraces of the Amalfi Coast}

The Amalfi Coast is a section of the Tyrrhenian Coast located in the Campania region (southern Italy) (Fig. 1a). The area belongs to the Mediterranean bioclimatic zone, with irregular but sometimes heavy rains. It is typified by climatic features in transition between the Mediterranean and temperate bioclimates (sensu Rivas Martinez 1993) (Savo et al. 2016). Here, annual rainfall amounts are rather high (spanning between 1000 and $1800 \mathrm{~mm}$ per year) due to the presence of the Lattari mountains that cause the condensation and precipitation of wet air masses (Savo et al. 2014, 2016). The average yearly temperature of the area is $18^{\circ} \mathrm{C}$, with average values of $20^{\circ}-21^{\circ} \mathrm{C}$ at the sea level, decreasing by $0.6^{\circ} \mathrm{C}$ for every increase of $100 \mathrm{~m}$ in elevation (Savo et al. 2007). Such mild temperatures, combined with the high rainfall, provide for the creation of specific microclimates, especially in the narrow valleys of the Coast, which explain the relictual presence of floristic elements belonging to the tropical climatic conditions of the Tertiary Era (Caneva and Cancellieri 2007). Mediterranean woodlands and shrublands represent the natural vegetation at lower altitudes and mesophilous mixed forests at higher elevations (Cancellieri et al. 2017).

The bedrock is carbonatic with a presence of pumices and other volcanic materials in the topsoil due to the past activity of the Vesuvius volcano, which is located in the proximity of the study site (Santo et al. 2007; Savo et al. 2014). Most of the mountainsides have been terraced and cultivated with lemon orchards in the lower belt and mostly vineyards and chestnut groves in the upper part (Caneva and Cancellieri 2007). Terraces have a flat surface (piazzola), which is mainly contained by stone walls (macerina), rarely by earth embankments (Caneva and Cancellieri 2007; Savo et al. 2014). The construction of terraces dates back to between 950 and 1025 AD. At that time, terraces had a significant diffusion, while since the fifties (after the Second World War), the agricultural sector has experienced a crisis, and terraces have been progressively abandoned since then (Caneva and Cancellieri 2007). In 2001, a survey on the extension of terraces within the area estimated a surface of 1629,40 ha, of which 340,78 ha (i.e., approximatively $21 \%$ ) were abandoned (Caneva et al. 2013).

\section{Materials and methods}

In our study, we combined semi-structured interviews with vegetation surveys on terrace walls. Considering the distribution of cultivated terraces in the area, we selected the municipalities with the highest distribution of terraces, such as Maiori, Minori, Amalfi, Positano (Fig. 1b) (Caneva and Cancellieri 2007). Then, we performed 30 interviews with local farmers on their terraces. Farmers were randomly selected within the study area, assuring the sampling of terraces at various altitudes and with different exposures. The semi-structured interviews were based on a questionnaire (Supplementary Information; SI 1) and had no time limit (Bernard 1988). We explained the scope of this study to each informant, and we verbally requested a Prior Informed Consent (Rosenthal 2006). Interviews were anonymous, and we followed International Codes of Ethics (e.g., ISE 2006). We respected the privacy of informants and avoided taking pictures of faces or homes. At the same time, we performed 34 vegetation surveys on the walls within the property of the interviewed farmers, following the phytosociological method (Braun-Blanquet 1932). The vegetation surveys were performed within a relatively wide altitudinal range (from 100 to $516 \mathrm{~m}$ ). During our surveys, we collected data on the exposure, altitude, wall type, species diversity, species cover, and we took several photos of each sampled plot. The dimension of the surveyed plots ranged between 10 and $20 \mathrm{~m}^{2}$. We gathered samples of plants, and we identified them using the Italian Flora (Pignatti 2017). For each species, we noted the life form and chorological type following Pignatti (2017). We updated the species nomenclature using The Plant List Version 1.1 (http://www.theplantlist.org/) and Bartolucci et al. (2018). Plant samples were prepared as herbarium vouchers and deposited at the herbarium of the University of Roma Tre (URT). A species/survey matrix was prepared and subjected to Cluster analysis (Ellison and Gotelli 2004) to evaluate the difference among the surveys on the basis of the different floristic patterns.

To better evaluate the features, ecology and potential dynamics of vegetation, we performed a syntaxonomical classification of the plant species, considering both rock and wall vegetation contributions and Mediterranean vegetation syntaxa (Brullo and Guarino 2002; Brullo and Spampinato 2003; Caneva 2004; Biondi et al. 2014; Brullo et al. 2020). The resulting syntaxa were later assigned to the plant species grouped into the resulting clusters. To reach a synthetic view, the plants belonging to the detected phytosociological classes were further grouped into four wider ecological groups: (1) rock and wall vegetation; (2) nitrophilous grasslands; (3) natural grasslands; (4) evolved stages of vegetation. For each species belonging 
to the four identified plant groups, we calculated the total covers starting from the cover values by Braun-Blanquet (1932), which were attributed in the field. Subsequently, we converted those values into the medium value of each cover range $(+=0.1 \% ; 1=2.5 \% ; 2=15.0 \% ; 3=37.5 \%$; $4=62.5 \% ; 5=87.5 \%$ ), and later we summed all the cover values of the plants belonging to the same cluster.

\section{Results}

\subsection{Risk factors for the stability of terraces}

On the Amalfi Coast, all the interviewed farmers are still cultivating crops and maintaining their terraces, which have been often in use for several generations (Fig. 1c). However, two farmers also have some terraces that are no longer cultivated within their farms. Farmers mostly grow lemons or grapes, often commercially, but also other fruits or vegetables for family consumption on their terraces (SI 2 Figure S1). Although we interviewed farmers who are still active, they were able to identify various risk factors also for abandoned terraces. The stability of the terrace system, according to the farmers, depends on several factors and management actions (Fig. 2). The first risk factor is the lack of maintenance of terraces and their retaining walls. Farmers also mentioned the potentially harmful effects of heavy rainfall and fires, especially for abandoned terraces and of animal breeding on either cultivated or abandoned terraces.

All the interviewed farmers still practice maintenance of the terraces even if they are no longer cultivating them to avoid their collapse. As noted by most informants (27 out of 30 informants), the first key factor in the management of terraces is maintaining waterways clear from debris to ensure an optimal rainwater runoff. Indeed, most farmers highlighted the linkage between terrace collapses and heavy

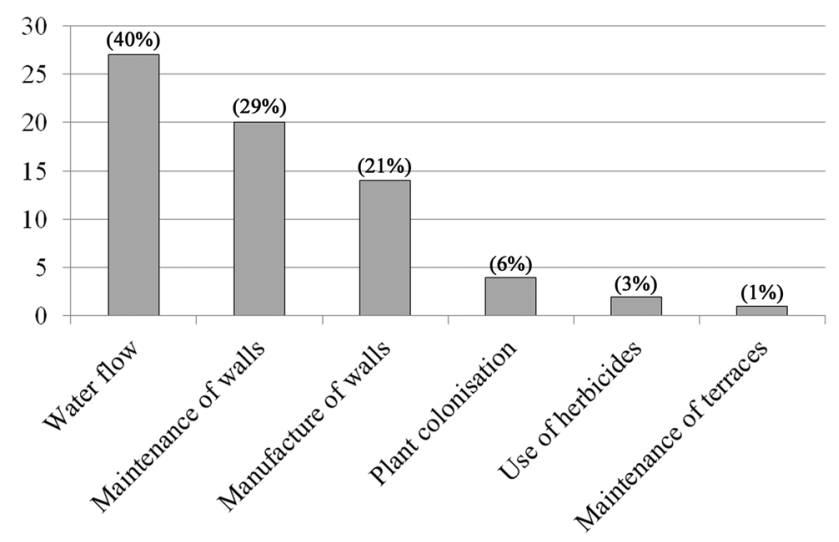

Fig. 2 Informants' opinions on the risk factors affecting the stability of terraces (above the bar, in brackets, the percentage of informants) rainfall. As noted by informants and by studies in the literature (e.g., Ramos 2016; Tarolli and Sofia 2016; Preti et al. 2018; Agnoletti et al. 2019), heavy rainfall remarkably contributes to causing deformations (i.e., bulging) of the stone walls and accelerating soil erosion, resulting as a major risk factor for the failure of terraces, especially of abandoned ones.

The second most relevant factor pertains to the maintenance of the retaining walls, which depends on their structure (Fig. 3). The embankments of the terraces on the Amalfi Coast are mostly made of dry stones (17 out of 34 relevees) or dry stones with inclusions of concrete (13 of 34 relevees); four informants have terraces reinforced with earth

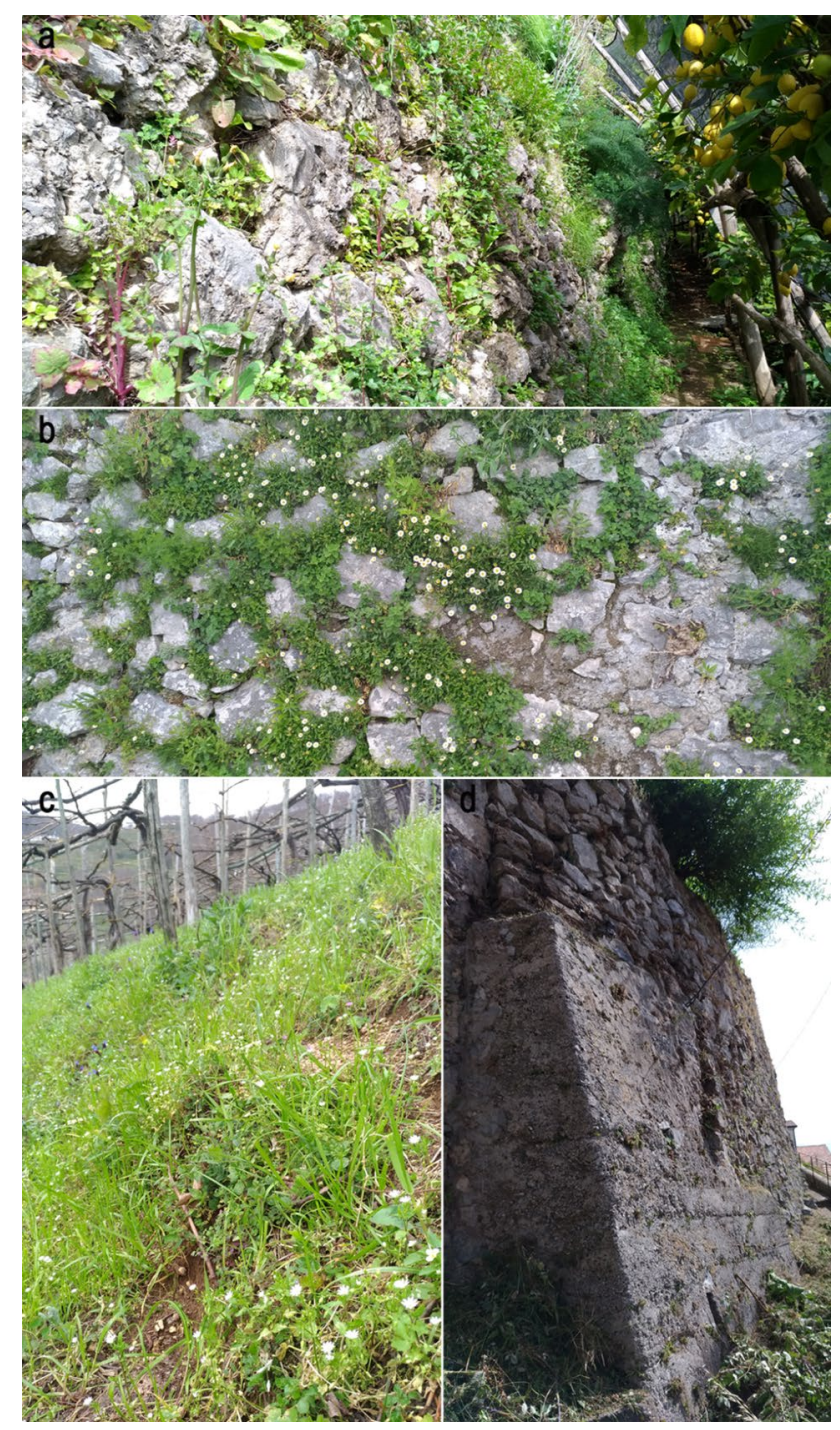

Fig. 3 a Dry stone terrace; b Dry stone and concrete terrace; c $A$ ripa terrace; $\mathbf{d}$ Concrete terrace. Terraces were mostly made of dry stone (17/34) or dry stone with inclusions of concrete (13/34); four informants had terraces with earth embankments (called a ripa), and only one had terraces with concrete retaining walls 
embankments (called "a ripa"), and only one has terraces with concrete retaining walls. These various types of retaining walls require different management actions, as detailed below.

Informants also highlighted other factors that, to some extent, might damage terraces. For instance, almost all the informants today do not let animals graze on terraces since they can damage the walls or the crops [as observed in Kizos et al. (2010)]. At the same time, informants noted that instead, in the past, it was common practice to keep grazing animals on the terraces to optimize the limited space: the animals were the only source of meat, and they contributed to keeping clean terraces and walls. Today these practices are no longer profitable due to the more restrictive regulations concerning animal breeding; however, some people still use to cut weeds (i.e., Parietaria sp. pl. or Centranthus ruber DC) from the walls as fodder for small animals such as hens or rabbits. Finally, although fires can damage terraces (Savo et al. 2014), farmers have noted that their incidence on cultivated areas is minimal for the relatively small amount of combustible material (e.g., dry plants) and for the easy access for rapid intervention.

\subsection{Vegetation on the terrace walls and plant management}

We recorded a certain diversity of plant species, primarily herbaceous, and with a Mediterranean distribution (109 species, 42 families) (SI 3 Table S1). Among the recorded species, two plants are endemic (Campanula fragilis Cirillo and Antirrhinum siculum Mill.) while three are invasive neophytes (Erigeron sumatrensis Retz, Phytolacca americana L. and Tradescantia fluminensis Vell.). Several species (10) are used as fodder, and many (36) have other uses (i.e., food plants, medicinal plants) (Savo 2009; Savo et al. 2011; Savo et al. 2015).

The number of species varied greatly among the surveys (from a minimum of three species to a maximum of 22), with an evident influence on the total cover. The elaborations carried out through the cluster analysis showed a separation of our surveys into two main clusters, characterized by a certain difference in the floristic patterns (Tables 1 and 2). A comparison of the weighted spectra of life forms of the two clusters highlighted some important differences: while the percentages of Chamaephytes (Ch), Geophytes $(\mathrm{G})$ and Phanerophytes (P) are somehow similar and comparable, with rather low values, Therophytes $(\mathrm{T})$ and Hemicryptophytes $(\mathrm{H})$ show a higher variability. In the first cluster, there is a total rate of Therophytes of $20 \%$ and of $67 \%$ of Hemicryptophytes, while in cluster II, the rate of $\mathrm{T}$ decreases to $7 \%$ and that of $\mathrm{H}$ increases to $79 \%$.

Analyzing the floristic patterns of the two clusters, we observed that, in general, the broader groups of plants were referable to the Stellarietea mediae and Artemisietea vulgaris classes (Tables 1 and 2), which describe slightly-nitrophylous and nitrophylous ephemeral and perennial vegetation (NIT) (Fig. 4) (Caneva 2004; Biondi et al. 2014). However, when considering the cover values of the plants, the species of rock and wall vegetation (WR), which mostly can be referred to the nitrophilous vegetation of the Parietarietea judaicae class (Brullo and Guarino 2002) and the non-nitrophilous vegetation of the Asplenietea trichomanis class, became the most relevant (Fig. 4). Species belonging to the classes Quercetea ilicis and Querco roboris-Fagetea sylvaticae (typical of evolved stages, such as garrigues and maquies, of the Mediterranean vegetation and of mesophylous Mediterranean forests, EV) are mostly found in the vegetation relevees grouped in cluster II (Table 2). Interestingly, the mesophilic species of the Querco roboris-Fagetea sylvaticae are only present in the relevees of cluster II. Some species typical of Mediterranean grasslands (MGR) (i.e., Lygeo sparti-Stipetea tenacissimae class) are present in both clusters, although with slightly higher cover values in the terraces of Cluster II.

The vegetation growing on the walls has a relevant role in the stability of terraces, according to the interviewed farmers. The management of dry stone walls requires removing plants growing among the stones and the replacement of fallen stones; most informants remove the plants by hand or using a brush cutter, avoiding the application of herbicides. The use of herbicides is frowned upon by several informants because they kill the whole plant, including the root system that (if it is herbaceous and not disruptive) is considered as integrated into the walls as a sort of plaster, and also because the produce is mostly for home consumption and farmers prefer healthy organic food. As regards dry stone walls (which are typical of the most common typology of terraces), the number of interventions per year affects (although not dramatically) the diversity and life forms of plants growing on the walls.

On dry stone walls, vegetation is removed twice or three times per year (Fig. 5a, b), while terraces with concrete inclusions need less frequent interventions (either plant removal or stone replacement). Farmers also replace fallen stones on occasion. On terrace walls with Southern expositions, plant removal occurs only once per year to still avoid the growth of woody species but, at the same time, to maintain a protective layer of vegetation that keeps the stones cool and reduces the overheating of the upstream embankment. The maintenance of the terraces "a ripa" (earth embankments), instead, implies only the mowing of the grass three, four times per year. Adherence to traditional construction techniques is also considered an essential factor for the durability and stability of terraces. 
Table 1 Cluster analysis (I) with identification of the vegetation classification

\begin{tabular}{lllllllllllllllll}
\hline Progressive code & 1 & 2 & 3 & 4 & 5 & 6 & 7 & 8 & 9 & 10 & 11 & 12 & 13 & 14 & 15 & 16 \\
\hline Altitude (m asl) & 100 & 250 & 353 & 291 & 160 & 170 & 390 & 128 & 335 & 341 & 372 & 335 & 369 & 565 & 517 & 125 \\
Slope ( $)^{\circ}$ & 85 & 80 & 85 & 80 & 80 & 85 & 85 & 85 & 85 & 85 & 85 & 80 & 85 & 85 & 85 & 85 \\
Exposure & NE & SE & S & SE & SSW & SSW & S & W & SE & ESE & E & SE & SE & E & NE & E \\
BUSH STRATUM & & & & & & & & & & & & & & & & \\
Avg Height (m) & - & - & - & - & - & - & - & - & - & - & - & - & - & 10 & - & 20 \\
Cover (\%) & - & - & - & - & - & - & - & - & - & - & - & - & - & 5 & - & 5 \\
HERB STRATUM & & & & & & & & & & & & & & & \\
Avg Height (m) & 10 & 20 & 40 & 30 & 40 & 10 & 20 & 20 & 20 & 20 & 15 & 20 & 20 & 20 & 30 & 30 \\
Cover (\%) & 80 & 40 & 50 & 80 & 60 & 30 & 40 & 70 & 40 & 70 & 40 & 50 & 40 & 40 & 40 & 60 \\
COVER & & & & & & & & & & & & & & \\
Bedrock (\%) & 20 & 60 & 50 & 20 & 40 & 80 & 60 & 20 & 60 & 30 & 60 & 50 & 60 & 60 & 60 & 40 \\
Soil (\%) & - & - & - & - & - & - & - & 10 & - & - & - & - & - & - & - & - \\
Surface (sqm) & 20 & 20 & 15 & 20 & 15 & 15 & 10 & 15 & 15 & 15 & 15 & 10 & 20 & 20 & 20 & 20 \\
Total number of species & 6 & 12 & 9 & 14 & 13 & 16 & 11 & 13 & 11 & 17 & 11 & 12 & 22 & 13 & 10 & 15
\end{tabular}

1. Wall and Rock Vegetation (Adiantetea capilli-veneris, Asplenietea trichomanis, Parietarietea judaicae, Sedo albi-Scleranthetea biennis)

\begin{tabular}{|c|c|c|c|c|c|c|c|c|c|c|c|c|c|c|c|}
\hline Parietaria judaica & & 2 & 2 & & & 2 & 2 & 2 & 1 & 2 & 2 & 2 & & & \\
\hline Ceterach officinarum & & & & & & 1 & 1 & + & 1 & + & 1 & + & + & & \\
\hline Cymbalaria muralis & & & + & & + & & + & 1 & & 1 & & & & 2 & + \\
\hline Umbilicus rupestris & & & & & 1 & + & 1 & 1 & & & 1 & + & & & \\
\hline Centranthus ruber & & & & 2 & & & 1 & & & & & 2 & & 2 & 2 \\
\hline Polypodium cambricum & & & & & 2 & & 2 & & & 1 & & + & & & \\
\hline Sonchus tenerrimus & & & 1 & + & & & & 1 & & & & & & & \\
\hline Veronica cymbalaria & & & & & & 1 & + & & & & & 1 & & & \\
\hline Selaginella kraussiana & & & & & & & & & 1 & & + & & & & \\
\hline Sedum dasyphyllum & & & & & & & & & & & 1 & 1 & & & \\
\hline Adiantum capillus-veneris & + & & & & & & & & & & & & & & \\
\hline Poa bulbosa & + & & & & & & & & & & & & & & \\
\hline Crepis neglecta & & & & + & & & & & & & & & & & \\
\hline Asplenium trichomanes & & & & & & & 1 & & & & & & & & \\
\hline Polypodium interjectum & & & & & & & & 1 & & & & & & & \\
\hline Asplenium ruta-muraria & & & & & & & & & & & 2 & & & & \\
\hline Capparis spinosa & & & & & & & & & & & & 1 & & & \\
\hline Cerastium semidecandrum & & & & & & & & & & & & & + & & \\
\hline Campanula fragilis & & & & & & & & & & & & & & & 1 \\
\hline
\end{tabular}

2. Slightly-nitrophylous and nitrophylous ephemeral and perennial vegetation (Artemisietea vulgaris, Polygono arenastri-Poetea annuae, Stellarietea mediae)

Parietaria officinalis

Fumaria capreolata

Mercurialis annua

Stellaria media

Sonchus asper

Daucus carota

Cerastium glomeratum

Calystegia silvatica

Scrophularia peregrina

Campanula erinus

Papaver rhoeas

$$
4
$$

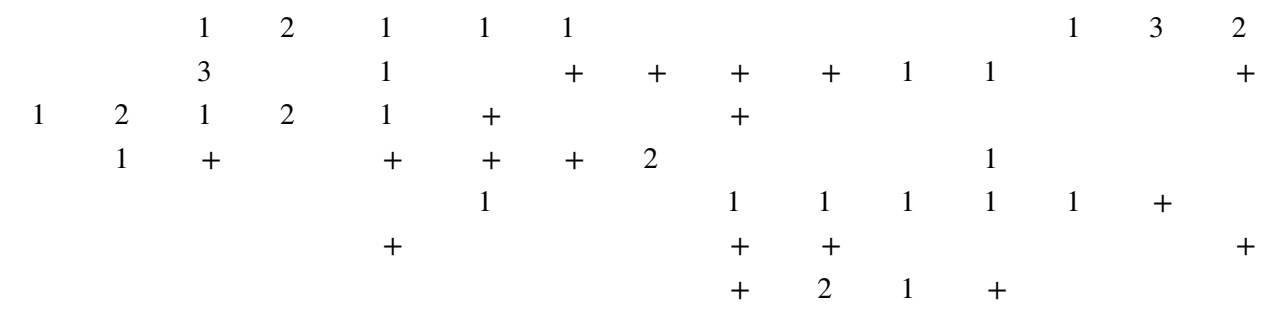

Avena barbata

Tradescantia fluminensis

Geranium dissectum

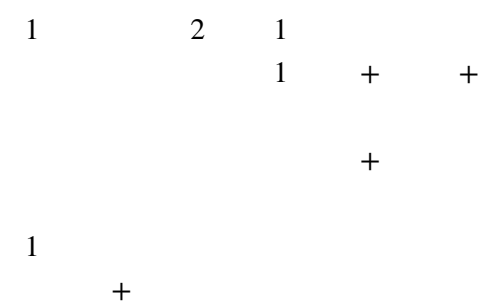


Table 1 (continued)

\begin{tabular}{|c|c|c|c|c|c|c|c|c|c|c|c|c|c|c|c|c|}
\hline Progressive code & 1 & 2 & 3 & 4 & 5 & 6 & 7 & 8 & 9 & 10 & 11 & 12 & 13 & 14 & 15 & 16 \\
\hline Picris hieracioides & & + & & & & & & & & & & & & & & \\
\hline Setaria verticillata & & + & & & & & & & & & & & & & & \\
\hline Euphorbia helioscopia & & & & & + & & & & & & & & & & & \\
\hline Sonchus oleraceus & & & & & & 1 & & & & & & & & & & \\
\hline Urtica membranacea & & & & & & + & & & & & & & & & & \\
\hline Fumaria officinalis & & & & & & & + & & & & & & & & & \\
\hline Arum italicum & & & & & & & & + & & & & & & & & \\
\hline Urtica urens & & & & & & & & & 1 & & & & & & & \\
\hline Veronica arvensis & & & & & & & & & + & & & & & & & \\
\hline Medicago polymorpha & & & & & & & & & & 2 & & & & & & \\
\hline Silene latifolia subsp. alba & & & & & & & & & & 2 & & & & & & \\
\hline Artemisia vulgaris & & & & & & & & & & 1 & & & & & & \\
\hline Oxalis corniculata & & & & & & & & & & + & & & & & & \\
\hline Роа аппиа & & & & & & & & & & & & 1 & & & & \\
\hline Erigeron sumatrensis & & & & & & & & & & & & & 3 & & & \\
\hline Capsella bursa-pastoris & & & & & & & & & & & & & + & & & \\
\hline Senecio vulgaris & & & & & & & & & & & & & + & & & \\
\hline Lolium temulentum & & & & & & & & & & & & & & 1 & & \\
\hline Lolium rigidum & & & & & & & & & & & & & & & & 1 \\
\hline Geranium molle & & & & & & & & & & & & & & & & + \\
\hline
\end{tabular}

3. Mediterranean and slightly mesophylous grasslands (Tuberarietea guttatae, Festuco valesiacae-Brometea erecti, Lygeo sparti-Stipetea tenacissimae, Molinio-Arrhenantheretea)

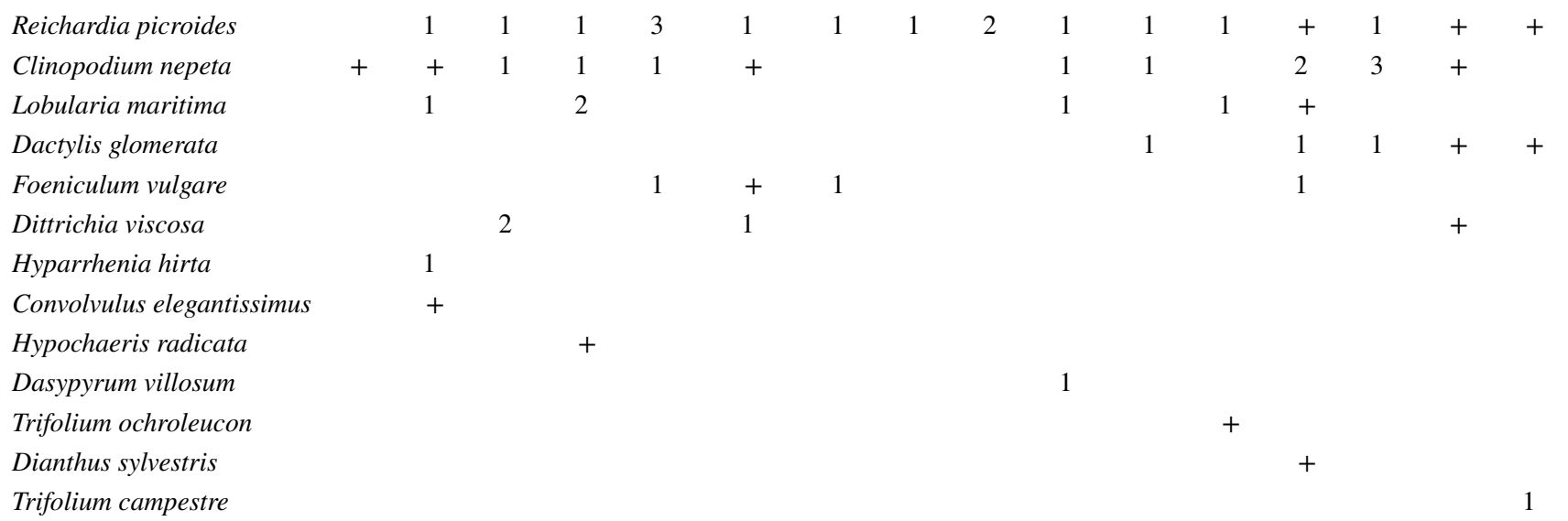

4. Evolved stages v/s Mediterranean garrigues and mesophilous Mediterranean forests (Cisto cretici-Micromerietea julianae, Rhamno catharticae-Prunetea spinosae, Quercetea ilicis, Querco roboris-Fagetea sylvaticae)
Achillea ligustica
Rubus ulmifolius
Micromeria graeca
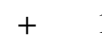
1

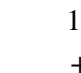
1

Others

Phytolacca americana

1

\section{Discussion}

Terraces are used to expanding cultivable land (Bevan and Conolly 2011), but they also alter the hydrogeology, soil features, and dynamics of mountainous areas (Stanchi et al. 2012; Nunes et al. 2018; Moreno-de-las-Heras et al.
2019). On the Amalfi Coast, terraces have been built since the $\mathrm{X}$ century and have faced periods of expansion and abandonment across the centuries, shaping the landscape up to the current UNESCO's Cultural Heritage (Caneva and Cancellieri 2007). Terraces have been integrated into a suggestive natural landscape, creating an outstanding 
Table 2 Cluster analysis (II) with identification of the vegetation classification

\begin{tabular}{|c|c|c|c|c|c|c|c|c|c|c|c|c|c|c|c|c|c|c|}
\hline Progressive code & 17 & 18 & 19 & 20 & 21 & 22 & 23 & 24 & 25 & 26 & 27 & 28 & 29 & 30 & 31 & 32 & 33 & 34 \\
\hline Altitude (m asl) & 150 & 286 & 134 & 107 & 169 & 139 & 209 & 188 & 83 & 516 & 491 & 148 & 299 & 460 & 467 & 485 & 500 & 307 \\
\hline Slope $\left(^{\circ}\right)$ & 85 & 85 & 85 & 85 & 85 & 85 & 85 & 85 & 80 & 85 & 85 & 85 & 85 & 50 & 90 & 45 & 45 & 80 \\
\hline Exposure & $\mathrm{SE}$ & SE & $\mathrm{E}$ & $\mathrm{E}$ & SE & $\mathrm{N}$ & NE & SW & $\mathrm{N}$ & $\mathrm{S}$ & SE & $\mathrm{N}$ & SE & SW & SW & NE & SW & W \\
\hline \multicolumn{19}{|l|}{ BUSH STRATUM } \\
\hline Avg Height (m) & - & - & - & - & - & - & - & - & - & - & - & - & - & - & - & - & - & 1 \\
\hline Cover $(\%)$ & - & - & - & - & - & - & - & - & - & - & - & - & - & - & - & - & - & 20 \\
\hline \multicolumn{19}{|l|}{ HERB STRATUM } \\
\hline Avg Height (m) & 30 & 10 & 30 & 15 & 10 & 30 & 30 & 10 & 20 & 15 & 15 & 50 & 20 & 20 & 30 & 30 & 40 & 30 \\
\hline Cover $(\%)$ & 60 & 20 & 40 & 100 & 80 & 60 & 60 & 20 & 50 & 30 & 20 & 40 & 10 & 80 & 70 & 90 & 90 & 60 \\
\hline \multicolumn{19}{|l|}{ COVER } \\
\hline Bedrock (\%) & 40 & 80 & 60 & - & 20 & 40 & 40 & 80 & 50 & 70 & 80 & 60 & 90 & - & - & 10 & - & 40 \\
\hline Soil (\%) & - & - & - & - & - & - & - & - & - & - & - & - & - & 20 & 30 & - & 10 & - \\
\hline Surface (sqm) & 10 & 20 & 20 & 10 & 10 & 20 & 10 & 10 & 15 & 10 & 20 & 15 & 20 & 10 & 10 & 10 & 12 & 15 \\
\hline Total number of species & 7 & 6 & 7 & 5 & 4 & 4 & 8 & 3 & 12 & 7 & 9 & 10 & 4 & 19 & 17 & 14 & 16 & 16 \\
\hline \multicolumn{19}{|c|}{ 1. Wall and Rock Vegetation (Adiantetea capilli-veneris, Asplenietea trichomanis, Parietarietea judaicae, Sedo albi-Scleranthetea biennis) } \\
\hline Parietaria judaica & 2 & 1 & 2 & 5 & 4 & 4 & 3 & 2 & 3 & 1 & 1 & 1 & + & 1 & & + & & \\
\hline Cymbalaria muralis & & + & & + & & + & + & & & & 1 & & & & & & & \\
\hline Sonchus tenerrimus & 2 & & 1 & & & & & & + & & & & & & & & & \\
\hline Centranthus ruber & & & + & & & & & & & + & & & & & & & & 1 \\
\hline Asplenium trichomanes & & & & + & + & & & & + & & & & & & & & & \\
\hline Campanula fragilis & & & & & & & & & & + & 1 & & & & 2 & & & \\
\hline Adiantum capillus-veneris & & & & 1 & 1 & & & & & & & & & & & & & \\
\hline Selaginella kraussiana & & & & + & & & & & 3 & & & & & & & & & \\
\hline Antirrhinum siculum & & & & & & 1 & & & & & 1 & & & & & & & \\
\hline Sedum dasyphyllum & & & & & & & & & & & + & & + & & & & & \\
\hline Veronica cymbalaria & 1 & & & & & & & & & & & & & + & & & & \\
\hline Umbilicus rupestris & & & & & & & & + & & & & & & & & & & \\
\hline Polypodium interjectum & & & & & & & & & 1 & & & & & & & & & \\
\hline Crepis neglecta & & & & & & & & & + & & & & & & & & & \\
\hline Polypodium cambricum & & & & & & & & & & & & 1 & & & & & & \\
\hline Asplenium ruta-muraria & & & & & & & & & & & & & & & + & & & \\
\hline \multicolumn{19}{|c|}{$\begin{array}{l}\text { 2. Slightly-nitrophylous and nitrophylous ephemeral and perennial vegetation (Artemisietea vulgaris, Polygono arenastri-Poetea annuae, Stel- } \\
\text { larietea mediae) }\end{array}$} \\
\hline Mercurialis aпnиа & & & & & & + & + & & & & & + & & & & + & + & \\
\hline Sonchus asper & & & & & & & + & & & & + & 1 & & 1 & + & & & \\
\hline Stellaria media & & & & & & & + & & & & & & & 3 & 1 & 2 & 1 & \\
\hline Geranium molle & & & & & & & & & & & & & & 2 & + & & + & + \\
\hline $\begin{array}{l}\text { Anchusa undulata subsp. } \\
\text { hybrida }\end{array}$ & & & & & & & & & & & & & & 1 & 1 & 1 & 2 & \\
\hline Vicia sativa & & & & & & & & & & & & & & + & + & & 1 & \\
\hline Veronica arvensis & 1 & & & & & & & & & & & & & + & + & & & \\
\hline Urtica urens & & & & & & & & + & & & & & & & & 1 & 1 & \\
\hline Fumaria capreolata & & & & & & & & & & & & & & + & 1 & + & & \\
\hline Euphorbia helioscopia & & & & & & & & & & & & & & + & & 1 & + & \\
\hline Galium aparine & 1 & & & & & & & & & + & & & & & & & & \\
\hline Роа аппиа & + & & & & & & & & + & & & & & & & & & \\
\hline Solanum americanum & & & + & & & & & & & & & + & & & & & & \\
\hline Parietaria officinalis & & & 2 & & & & & & & & & & + & & & & & \\
\hline Matricaria chamomilla & & & & & & & + & & & & & 1 & & & & & & \\
\hline Campanula erinus & & & & & & & & & + & & + & & & & & & & \\
\hline
\end{tabular}


Table 2 (continued)

\begin{tabular}{|c|c|c|c|c|c|c|c|c|c|c|c|c|c|c|c|c|c|c|}
\hline Progressive code & 17 & 18 & 19 & 20 & 21 & 22 & 23 & 24 & 25 & 26 & 27 & 28 & 29 & 30 & 31 & 32 & 33 & 34 \\
\hline Lactuca muralis & & & & & & & & & + & & & + & & & & & & \\
\hline Lamium purpureum & & & & & & & & & & & & & & 1 & & & 1 & \\
\hline Senecio vulgaris & & & & & & & & & & & & & & + & & & 1 & \\
\hline Lolium multiflorum & & & & & & & & & & & & & & & & 3 & 4 & \\
\hline Silene latifolia subsp. alba & & & & & & & & & & & & & & & & 1 & 2 & \\
\hline Calystegia silvatica & & + & & & & & & & & & & & & & & & & \\
\hline Euphorbia peplus & & & & & & & + & & & & & & & & & & & \\
\hline Arum italicum & & & & & & & & & + & & & & & & & & & \\
\hline Linaria vulgaris & & & & & & & & & & + & & & & & & & & \\
\hline Chenopodium album & & & & & & & & & & & & 1 & & & & & & \\
\hline Chelidonium majus & & & & & & & & & & & & & & + & & & & \\
\hline Rumex acetosella & & & & & & & & & & & & & & + & & & & \\
\hline Viola tricolor & & & & & & & & & & & & & & + & & & & \\
\hline Avena barbata & & & & & & & & & & & & & & & 1 & & & \\
\hline Erigeron sumatrensis & & & & & & & & & & & & & & & 1 & & & \\
\hline Sherardia arvensis & & & & & & & & & & & & & & & 1 & & & \\
\hline Fumaria officinalis & & & & & & & & & & & & & & & & + & & \\
\hline Picris hieracioides & & & & & & & & & & & & & & & & & & + \\
\hline
\end{tabular}

3. Mediterranean and slightly mesophylous grasslands (Tuberarietea guttatae, Festuco valesiacae-Brometea erecti, Lygeo sparti-Stipetea tenacissimae, Molinio-Arrhenantheretea)

\section{Lobularia maritima}

Dactylis glomerata

Bromus erectus

Bituminaria bituminosa

Dittrichia viscosa

Foeniculum vulgare

Hypochaeris radicata

Brachypodium pinnatum

Poa trivialis

Ajuga reptans

Clinopodium nepeta

Anthoxanthum odoratum

Brachypodium retusum

Ferula communis

Reichardia picroides

4. Evolved stages v/s Mediterranean garrigues and mesophilous Mediterranean forests (Cisto cretici-Micromerietea julianae, Rhamno catharticae-Prunetea spinosae, Quercetea ilicis, Querco roboris-Fagetea sylvaticae)

Hedera helix

2

Pteridium aquilinum

Carex halleriana

Achillea ligustica

Arisarum vulgare

Micromeria graeca

Rubus ulmifolius

Brachypodium sylvaticum

Lamium flexuosum

Ficaria verna

Cyclamen hederifolium

Fraxinus ornus

Pistacia lentiscus
1

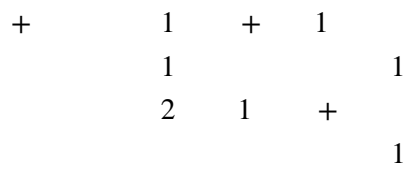

1

2

1

$+$

1 
Table 2 (continued)

\begin{tabular}{|c|c|c|c|c|c|c|c|c|c|c|c|c|c|c|c|c|c|c|}
\hline Progressive code & 17 & 18 & 19 & 20 & 21 & 22 & 23 & 24 & 25 & 26 & 27 & 28 & 29 & 30 & 31 & 32 & 33 & 34 \\
\hline Polystichum setiferum & & & & & & & & & & & & & & & & & & 1 \\
\hline Quercus pubescens & & & & & & & & & & & & & & & & & & + \\
\hline \multicolumn{19}{|l|}{ Others } \\
\hline Centranthus calcitrapa & & & & & & & & & & + & & & & & & & & \\
\hline Helichrysum italicum & & & & & & & & & & & + & & & & & & & \\
\hline
\end{tabular}

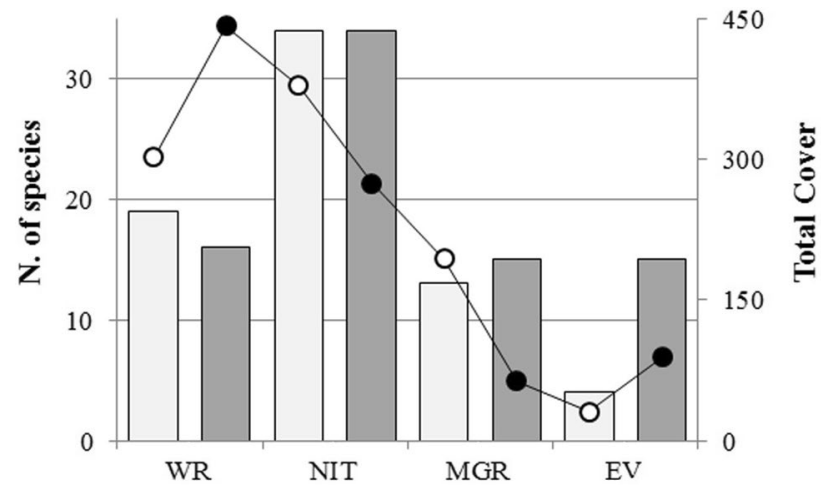

Fig. 4 Number of species and their total cover in the two resulting clusters, referred to the four main ecological groups of plants growing on terrace walls on the Amalfi Coast. WR Walls and Rocks Vegetation, NIT Slightly-nitrophylous and nitrophylous ephemeral and perennial vegetation, $M G R$ Mediterranean and slightly mesophylous grasslands, $E V$ Evolved stages v/s Mediterranean garrigues and mesophilous Mediterranean forests. Columns refer to the number of species in the two clusters (Bright gray $=$ Cluster I; Dark gray $=$ Cluster II); Dots refer to the total cover of the species in the two clusters (White dots $=$ Cluster I; Black dots =Cluster II). The total cover corresponds to the sum of the cover of all the species of each group in the two clusters

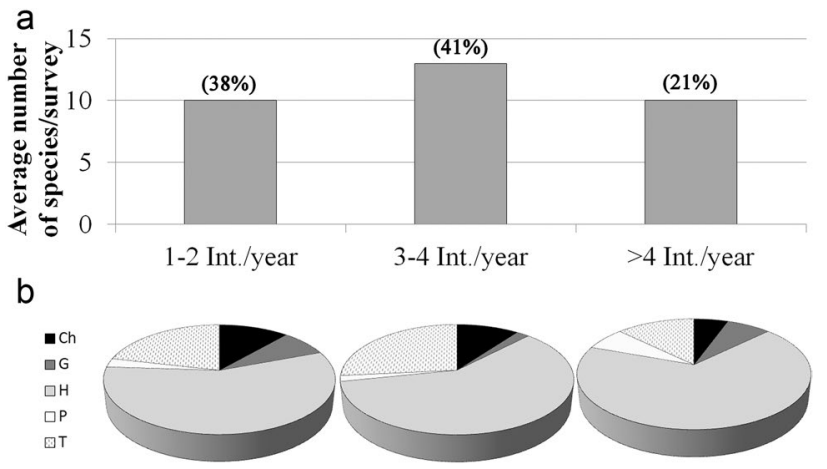

Fig. 5 a Average number of species (per survey) in relation to the number of interventions (Int.) each year (above the bar, in brackets, the percentage of informants); b Life forms of species in relation to the number of interventions each year $(\mathrm{Ch}=$ Chamaephytes and $\mathrm{P}=$ Phanerophytes are short or tall woody species; $\mathrm{T}=$ Therophytes (ephemeral); $\mathrm{H}=$ Hemicryptophytes and $\mathrm{G}=$ Geophytes are perennial herbaceous species) example of a cultural landscape. These terraced landscapes, along with other natural and cultural attractions (i.e., beaches, cliffs, villages and monuments) of the area, every year attract thousands of tourists from all over the world.

Today, terraces and the cultural landscape that they have shaped are threatened by a variety of factors. Although we have not recorded the exact age of our informants, they were mostly old, with the likely possibility that their terraces will be no longer cultivated once they retire. If not adequately managed, terraces can collapse, and debris can build up and move downslope with heavy rainfall, causing landslides (Moreno-de-las-Heras et al. 2019). The periodical maintenance of terraces is essential for erosion control, runoff control, hydrogeological stability, and connectivity (García-Ruiz and Lana-Renault 2011; García-Ruiz et al. 2013; Moreno-de-las-Heras 2019); but it is also pivotal for landscape preservation (Petanidou et al. 2008).

The various management actions had a high consensus among farmers, suggesting that their Local Ecological Knowledge is built on shared observations and experiences. These three management actions (removing vegetation from the walls, keeping waterways clear, and repairing walls) are also reported in the literature (e.g., Di Fazio 2008; Palmer et al. 2010; Momirski and Gabrovec 2014); however, each author tend to stress one or two actions, and generally the details on vegetation control are missing. Most informants noted that clearing waterways periodically and removing vegetation from the walls two or three times per year is generally enough to assure the functionality of the terrace system and avoid collapses. The importance of maintaining water drainage is widely underlined in the literature, and for instance, Preti et al. (2018) suggest that this strategy might be useful to reduce the incidence of wall deformations. On the Amalfi Coast, over the centuries, farmers have developed an intricate network of channels and waterways to convey spring waters to the fields but also to drain outflow waters from the terraces (Caneva and Cancellieri 2007). Repairing damaged walls can be challenging, but the restoration of collapsed terraces is more expensive and demanding than periodic maintenance, and terraces are not always restored using traditional construction techniques as in our set of analyzed 
terraces, we found several with concrete inclusions (see also Stanchi et al. 2012).

The management of vegetation on the embankments is also a pivotal management strategy. As regards dry stone walls, plants are cut and then sometimes used as feed for small animals or, in some instances (e.g., Reichardia picroides (L.) Roth, Sonchus oleraceus L.), are used by farmers to prepare salads or soups. However, we were not able to demonstrate if farmers were favouring the growth of useful species on their walls. Arguably, it is possible that, in the past, farmers applied some selection criteria during the removal of the vegetation to optimize labour, benefits, and resources. Today, clearing management strategies tend only to favour herbaceous species, which generally are not harmful to stone structures (Caneva et al. 2018; Cicinelli et al. 2018). Chamaephytes and Phanerophytes, which produce a more robust root system, instead, can damage structures by moving the stones and reducing the adhesion between them (Caneva et al. 2008), and resulted poorly represented among the plants colonizing the walls (around $11 \%$ of the total cover). As regards earth embankments, the grass is mowed and then often used as a fooder. In the past, farmers would simply let the animals graze on the terraces, a practice that is not quite common in the Mediterranean area (Segui 1999) and today it is no longer practiced on the Amalfi Coast.

The vegetation analysis reinforced the findings of our interviews. The managed terrace walls are mostly dominated by annual species typical of the Stellarietea mediae, thus plants with a smaller root apparatus that is not harmful to the terrace structures. Most species are nitrophilous or subnitrophilous ruderal plants that are not surprising to find in the proximity of agricultural fields. The cover of typical nitrophilous perennial wall plants, such as Parietaria judaica, together with Parietaria officinalis, resulted, however, potentially dangerous for the stability of the walls. We also found species typical of natural habitats of the Quercetea ilicis, highlighting the Mediterranean character of the area, and Querco roboris-Fagetea sylvaticae mostly in cluster II, which resulted in closer connection with natural vegetation. The lower cover of such classes in cluster I may also depend on more intensive management activities on the terraces, which prevent the natural evolution of the spontaneous vegetation (Palmer et al. 2010).

According to the literature, there are different potential futures for abandoned terraces. They can be recolonized by natural vegetation, whose cover and dynamics depend on the time since abandonment (e.g., Ruecker et al. 1998; Poyatos et al. 2003; Bonet 2004; Rühl et al. 2006; Koulouri and Giourga 2007; Palmer et al. 2010), soil and aspect (e.g., Blasi et al. 2000; Cyffka 2006; Rühl et al. 2006; Barbera et al. 2010) and previous land use (e.g., Douglas et al. 1996; Ginés 1999; Cyffka and Bock 2008). In this case, the progressive growth of plants belonging to evolved stages will re-establish the natural forest communities, with a collapse of terraces, but without landslides, since wooden roots, after the initial penetration, can then expand, surround and englobe the ruined walls. A similar phenomenon was often observed in the case of abandonment of archaeological sites with a subsequent plant recolonization (Caneva 2004; Caneva et al. 2005). However, vegetation recolonization is dynamic (Ingegnoli and Pignatti 2007) and can be disturbed by fires or grazing, which can reduce plant cover and promote soil erosion with potential impacts on terrace stability and landslide risks (Moreno-de-las-Heras 2019). In any case, the loss of terraces results in the loss of a cultural landscape of high relevance and, consequently, it can cause irreparable damage to the local traditions, identity, sense of place and cultural ecosystem services (Vos and Meekes 1999; Schaich et al. 2010). In this perspective, any action aimed at preventing and reducing the loss of terraces is valuable (Antrop 2005; Kladnik et al. 2017). The preservation of traditional agriculture and related practices is thus pivotal for safeguarding natural and cultural landscapes, which are becoming increasingly relevant in the Mediterranean area (Caneva et al. 2018; Cicinelli et al. 2018).

\section{Conclusions}

The management of terraces on the Amalfi Coast is still carried out by the farmers, even if abandonment is increasingly becoming a threat to the cultural landscapes of the Coast. According to our study, it seems that simple, uncostly actions can prevent, or at least reduce, the incidence of landslides. Finding ways to maintain vital agriculture on the Amalfi Coast thus becomes a priority for the conservation of the cultural landscape (and related LEK) that has contributed to making the area a UNESCO Cultural Heritage site.

Supplementary Information The online version contains supplementary material available at https://doi.org/10.1007/s12210-021-01018-9.

Acknowledgements We are thankful to the informants of the Amalfi Coast that shared their knowledge with us. The Grant to the Department of Science, Roma Tre University (MIUR-Italy Dipartimenti di Eccellenza, ARTICOLO 1, COMMI 314-337 LEGGE 232/2016) is gratefully acknowledged.

Author contributions EC and VS gathered the field data; EC, VS, and $\mathrm{GC}$ wrote the manuscript together.

Funding Open access funding provided by Università degli Studi Roma Tre within the CRUI-CARE Agreement. The Ph.D. scholarship of Emanuela Cicinelli was granted by the University Roma Tre. 
Availability of Data and Material Supplementary files are available here SI 1, SI 2, SI 3.

\section{Declarations}

Conflict of interest The authors declare no competing interests.

\section{Ethics approval Not Applicable.}

Consent to participate We explained the scope of this study to each informant, and we verbally requested Prior Informed Consent. Interviews were anonymous.

\section{Consent for publication Not Applicable.}

Code availability Not Applicable.

Open Access This article is licensed under a Creative Commons Attribution 4.0 International License, which permits use, sharing, adaptation, distribution and reproduction in any medium or format, as long as you give appropriate credit to the original author(s) and the source, provide a link to the Creative Commons licence, and indicate if changes were made. The images or other third party material in this article are included in the article's Creative Commons licence, unless indicated otherwise in a credit line to the material. If material is not included in the article's Creative Commons licence and your intended use is not permitted by statutory regulation or exceeds the permitted use, you will need to obtain permission directly from the copyright holder. To view a copy of this licence, visit http://creativecommons.org/licenses/by/4.0/.

\section{References}

Agnoletti M, Conti L, Frezza L, Santoro A (2015) Territorial analysis of the agricultural terraced landscapes of Tuscany (Italy): preliminary results. Sustainability 7(4):4564-4581

Agnoletti M, Errico A, Santoro A, Dani A, Preti F (2019) Terraced landscapes and hydrogeological risk effects of land abandonment in Cinque Terre (Italy) during severe rainfall events. Sustainability 11(1):235

Andlar G, Šrajer F, Trojanović A (2017) Classifying the Mediterranean terraced landscape: the case of Adriatic Croatia. Acta Geogr Slov 57(2):111-129

Antrop M (2005) Why landscapes of the past are important for the future. Landsc Urban Plan 70(1-2):21-34

Arnáez J, Lana-Renault N, LasantaT R-F, Castroviejo J (2015) Effects of farming terraces on hydrological and geomorphological processes: a review. CATENA 128:122-134

Baiamonte G, Domina G, Raimondo FM, Bazan G (2015) Agricultural landscapes and biodiversity conservation: a case study in Sicily (Italy). Biodivers Conserv 24:3201-3216

Barbera G, Cullotta S, Rossi-Doria I, Rühl J, Rossi-Doria B (2010) I Paesaggi a Terrazze in Sicilia: Metodologie per l'analisi, la tutela e la valorizzazione. ARPA Sicilia, Palermo

Bartolucci F, Peruzzi L, Galasso G, Albano A, Alessandrini AN, Ardenghi NM, Astuti G, Bacchetta G, Ballelli S, Banfi E, Barberis $\mathrm{G}$ (2018) An updated checklist of the vascular flora native to Italy. Plant Biosyst 152(2):179-303

Berkes F, Colding J, Folke C (2000) Rediscovery of traditional ecological knowledge as adaptive management. Ecol Appl 10:1251-1262

Bernard HR (1988) Research Methods in Cultural Anthropology. Sage, Beverly Hills
Bevan A, Conolly J (2011) Terraced fields and Mediterranean landscape structure: an analytical case study from Antikythera. Greece Ecol Model 222(7):1303-1314

Biondi E, Blasi C, Allegrezza M, Anzellotti I, Azzella MM, Carli E, Casavecchia S, Copiz R, Del Vico E, Facioni L, Galdenzi D (2014) Plant communities of Italy: the vegetation prodrome. Plant Biosyst 148:728-814

Blasi C, Di Pietro R, Fortini P (2000) A phytosociological analysis of abandoned terraced olive grove shrublands in the Tyrrhenian district of Central Italy. Plant Biosyst 134(3):305-331

Bonet A (2004) Secondary succession of semi-arid Mediterranean old-fields in south-eastern Spain: insights for conservation and restoration of degraded lands. J Arid Environ 56(2):213-233

Braun-Blanquet J (1932) Plant sociology The study of plant communities. McGraw-Hill Book Co. Inc, London

Brullo S, Guarino R (2002) La classe Parietarietea judaicae OBERD. 1977 in Italia. Fitosociologia 39(1):5-27

Brullo S, Spampinato G (2003) La classe Asplenietea trichomanis in Calabria (Italia meridionale). Fitosociologia 40(1):5-22

Brullo S, Brullo C, Cambria S, Giusso del Galdo G (2020) Xerophilous Grasslands. In: Brullo S, Brullo C, Cambria S, del Galdo GG (eds) The Vegetation of the Maltese Islands. Springer, Cham, pp 157-177

Cancellieri L, Caneva G, Cutini M (2017) Phytosociology and ecology of the Mediterranean forests ecosystems in the Amalfi Coast (Monti Lattari, Italy). Rend Fis Acc Lincei 28(4):651-671

Caneva G, Salvadori O, Ricci S, Ceschin S (2005) Ecological analysis and biodeterioration processes over time at the Hieroglyphic Stairway in the Copán (Honduras) archaeological site. Plant Biosyst 139(3):295-310

Caneva G, Nugari MP, Salvadori O (eds) (2008) Plant biology for cultural heritage: biodeterioration and conservation. Getty Publications, Los Angeles

Caneva G, Benelli F, Bartoli F, Cicinelli E (2018) Safeguarding natural and cultural heritage on Etruscan tombs (La Banditaccia, Cerveteri, Italy). Rend Fis Acc Lincei 29(4):891-907

Caneva G, Cancellieri L (2007) Vegetation landscape of the Amalfi Coast. Gangemi Ed., Rome

Caneva G, Rossi D, Salvati L, Savo V (2007). Environmental risk analysis in relationship with rainfall: the Amalfi Coast as a case of study. In: Conference Proceedings of the SIS Conference 2007 "Rischio e previsione", Jun 6-8 2007; Venice. pp 613-614.

Caneva G, Cancellieri L, Tufano M, Savo V (2013) Indicazioni gestionali su Agricoltura, Etnobotanica e Aree di interesse naturalistico (con considerazioni sui possibili effetti del cambiamento climatico). In: Ferrigni F, Sorrentino MC (eds). Il futuro dei Territori antichi. Problemi, Prospettive e Questioni di Governance dei Paesaggi Culturali Evolutivi Viventi. EdiPuglia, Bari, pp 167-178

Caneva G (Ed) (2004) Amphytheatrum Naturae - Il Colosseo: storia e ambiente letti attraverso la sua flora. Ed. Electa Ed., Milan

Caneva G (2010) Cultural landscapes and climate change. In: Lefèvre RA, Sabbioni C (eds). Climate change and cultural heritage, Edipuglia, Bari

Cicinelli E, Salerno G, Caneva G (2018) An assessment methodology to combine the preservation of biodiversity and cultural heritage: the San Vincenzo al Volturno historical site (Molise, Italy). Biodivers Conserv 27:1073-1093

Cicinelli E, Caneva G, Savo V (2021) A review on management strategies of the terraced agricultural systems and conservation actions to maintain cultural landscapes around the Mediterranean Area. Sustainability 13(8):4475

Cyffka B (2006) Experiences in the study of land cover transformation on Mediterranean islands caused by change in land tenure. In: Vogtmann H, Dobretsov N (eds) Environmental Security and 
Sustainable Land Use-with special reference to Central Asia. Springer, Dordrecht, pp 85-103

Cyffka B, Bock M (2008) Degradation of field terraces in the Maltese Islands-reasons, processes and effects. Dinamica Quaternaria 31:119-128

Di Fazio S (2008) I terrazzamenti viticoli della Costa Viola Caratteri distintivi del paesaggio, trasformazioni in atto e gestione territoriale in un caso-studio in Calabria. I Georgofil Quaderni II:69-92

Doolittle WE (1990) Terrace origins: hypotheses and research strategies. Yearbook, Conference of Latin Americanist Geographers 16:94-97

Douglas T, Critchley D, Park G (1996) The deintensification of terraced agricultural land near Trevelez, Sierra Nevada, Spain. Glob Ecol Biogeogr 5:258-270

Ellison GN, Gotelli NJ (2004) A primer of ecological statistics. Sinauer, Sunderland

García-Ruiz JM, Lana-Renault N (2011) Hydrological and erosive consequences of farmland abandonment in Europe, with special reference to the Mediterranean region-a review. Agric Ecosyst Environ 140(3-4):317-338

García-Ruiz JM, Nadal-Romero E, Lana-Renault N, Beguería S (2013) Erosion in Mediterranean landscapes: changes and future challenges. Geomorphology 198:20-36

Ginés Á (1999) Agriculture, grazing and land changes at the Serra de Tramuntana karstic mountains. Int J Speleol 28(1):1

Hribar MŠ, Geršič M, Pipan P, Repolusk P, Tiran J, Topole M (2017) Cultivated terraces in Slovenian landscapes. Acta Geogr Slov 57(2):83-97

Ingegnoli V, Pignatti S (2007) The impact of the widened landscape ecology on vegetation science: towards the new paradigm. Rend Fis Acc Lincei 18(2):89-122

ISE (International Society of Ethnobiology) (2006) ISE Code of Ethics (with 2008 additions) www.ethnobiology.net/ethics.php

Kizos T, Koulouri M, Vakoufaris H, Psarrou M (2010) Preserving characteristics of the agricultural landscape through agri-environmental policies: the case of cultivation terraces in Greece. Landsc Res 35:577-593

Kladnik D, Šmid Hribar M, Geršič M (2017) Terraced landscapes as protected cultural heritage sites. Acta Geogr Slov 57(2):131-148

Koulouri M, Giourga C (2007) Land abandonment and slope gradient as key factors of soil erosion in Mediterranean terraced lands. CATENA 69(3):274-281

Momirski LA, Gabrovec M (2014) Changes in land use in the Mediterranean terraced landscapes between 1819 and 2012: the case of two selected villages in Slovenia. In: Himiyama Y, Mather A, Bicik I, Milanova EV (eds) Land use, cover changes in selected regions in the world. IGU-LUCC, Hokkaido, pp 33-42

Moreno-de-las-Heras M, Lindenberger F, Latron J, Lana-Renault N, Llorens P, Arnáez J, Romero-Díaz A, Gallart F (2019) Hydro-geomorphological consequences of the abandonment of agricultural terraces in the Mediterranean region: Key controlling factors and landscape stability patterns. Geomorphology 333:73-91

Nunes JP, Bernard-Jannin L, Rodriguez Blanco ML, Santos JM, Coelho CD, Keizer JJ (2018) Hydrological and erosion processes in terraced fields: observations from a humid Mediterranean region in Northern Portugal. Land Degrad Dev 29(3):596-606

Palmer C, Colledge S, Bevan A, Conolly J (2010) Vegetation recolonisation of abandoned agricultural terraces on Antikythera Greece. Environ Archaeol 15:64-80

Petanidou T, Kizos T, Soulakellis N (2008) Socioeconomic dimensions of changes in the agricultural landscape of the Mediterranean basin: a case study of the abandonment of cultivation terraces on Nisyros Island, Greece. Environ Manag 41(2):250-266

Pignatti S (2017) Flora d'Italia. Edagricole, Bologna
Pipan P, Kokalj Ž (2017) Transformation of the Jeruzalem Hills cultural landscape with modern vineyard terraces. Acta Geogr Slov 57(2):149-162

Poyatos R, Latron J, Llorens P (2003) Land use and land cover change after agricultural abandonment. Mt Res Dev 23(4):362-369

Preti F, Errico A, Caruso M, Dani A, Guastini E (2018) Dry-stone wall terrace monitoring and modelling. Land Degrad Dev 29(6):806-1818

Ramos MC (2016) Soil losses in rainfed Mediterranean vineyards under climate change scenarios. The effects of drainage terraces. AIMS Agric Food 1:124-143

Rivas Martinez S (1993) Bases para una nueva clasificaciòn bioclimatica de la tierra. Folia Botanica Matritensis 10:1-23

Rosenthal J (2006) Politics, culture, and governance in the development of prior informed consent in indigenous communities. Curr Anthropol 47(1):119-142

Ruecker G, Schad P, Alcubilla MM, Ferrer C (1998) Natural regeneration of degraded soils and site changes on abandoned agricultural terraces in Mediterranean Spain. Land Degrad Dev 19:488-501

Rühl J, Pasta S, Schnittler M, Univ P (2006) A chronosequence study of vegetation dynamics on abandoned vine and caper terraces of Pantelleria Island (Sicily). Arch Nat Conserv Landsc Res 45(1):71-94

Santo A, Del Prete S, Di Crescenzo G, Rotella M (2007) Karst processes and slope instability: some investigations in the carbonate Apennine of Campania (Southern Italy). Geol Soc Lond Spec Publ 279:59-72

Savo V, Caneva G, McClatchey W, Reedy D, Salvati L (2014) Combining environmental factors and agriculturalists' observations of environmental changes in the traditional terrace system of the Amalfi Coast (Southern Italy). Ambio 43:297-310

Savo V, Joy R, Caneva G, McClatchey WC (2015) Plant selection for ethnobotanical uses on the Amalfi Coast (Southern Italy). J Ethnobiol Ethnomedicine 11:58

Savo V, Salvati L, Caneva G (2016) In-between soil erosion and sustainable land management: climate aridity and vegetation in a traditional agro-forest system (Costiera Amalfitana, southern Italy). Int J Sust Dev World 23(5):423-432

Savo V, Rossi D, Salvati L, Caneva G (2007) Lineamenti sulle caratteristiche fisiche del territorio. In: Caneva G, Cancellieri L (eds). Il paesaggio vegetale della Costa d'Amalfi. Gangemi Ed., Rome, pp 13-32

Savo V, Caneva G, Guarrera PM, Reedy D (2011) Folk phytotherapy of the Amalfi coast (Campania, Southern Italy). J Ethnopharmacol 135(2):376-392

Savo V (2009) Ethnobotanical analysis in the Amalfi Coast and evaluation of results on a scientific and economic point of view. Doctoral dissertation, University of Roma Tre

Schaich H, Bieling C, Plieninger T (2010) Linking ecosystem services with cultural landscape research. Gaia 19(4):269-277

Segui JR (1999) Traditional pastoralism in the Fageca and Famorca villages (Mediterranean Spain): An ethnoarchaeological approach. Doctoral dissertation, University of Leicester

Solomou A, Proutsos N, Karetsos G, Tsagkari K (2020) Impact of Stone Terraces and Walls Micro-environment on Biodiversity Conservation: A Case Study in the Mediterranean Island of Kythira-Greece. In: Conference Proceedings of the HAICTA Conference 2020, Sept. 24-26 2020; Thessaloniki. pp 549-557

Spencer JE, Hale GA (1961) The origin, nature, and distribution of agricultural terracing. Pacific Viewpoint 2(1):1-40

Stanchi S, Freppaz M, Agnelli A, Reinsch T, Zanini E (2012) Properties, best management practices and conservation of terraced soils in Southern Europe (from Mediterranean areas to the Alps): a review. Quat Int 265:90-100 
Tarolli P, Sofia G (2016) Human topographic signatures and derived geomorphic processes across landscapes. Geomorphology 255:140-161

Treacy JM, Denevan WM (1997) The creation of cultivable land through terracing. In: Miller NF, Gleason KL (eds) The archaeology of garden and field. University of Pennsylvania Press, Philadelphia, pp 91-110

UNESCO (1997) Convention concerning the protection of the World Cultural and Natural Heritage https://whc.unesco.org/archive/ 1997/whc-97-conf208-17e.pdf

Van der Sluis T, Kizos T, Pedroli GB (2014) Landscape change in Mediterranean farmlands: Impacts of land abandonment on cultivation terraces in Portofino (Italy) and Lesvos (Greece). J Land Ecol 7(1):23-44

Varotto M, Ferrarese F, Pappalardo SE (2019) Italian Terraced Landscapes: The Shapes and the Trends. In: Varotto M, Bonardi L, Tarolli P (eds) World Terraced Landscapes: History, Environment, Quality of Life. Springer, Cham, pp 27-43
Vos W, Meekes H (1999) Trends in European cultural landscape development: perspectives for a sustainable future. Landsc Urban Plan 46(1-3):3-14

Wei W, Chen D, Wang L, Daryanto S, Chen L, Yu Y, Lu Y, Sun G, Feng T (2016) Global synthesis of the classifications, distributions, benefits and issues of terracing. Earth-Sci Rev 159:388-403

Zoumides C, Bruggeman A, Giannakis E, Camera C, Djuma H, Eliades M, Charalambous K (2017) Community-based rehabilitation of mountain terraces in Cyprus. Land Degrad Dev 28(1):95-105

Publisher's Note Springer Nature remains neutral with regard to jurisdictional claims in published maps and institutional affiliations. 